\title{
Mitochondrial Dysfunction in Metabolic Disease
}

\author{
Anna Meiliana ${ }^{1,2 *}$ and Andi Wijaya ${ }^{1,2 *}$
}

\begin{abstract}
${ }^{1}$ Post Graduate Program in Clinical Biochemistry, Hasanuddin University, Jl. Perintis Kemerdekaan Km.10. Makassar, Indonesia
${ }^{2}$ Prodia Clinical Laboratory, Jl. Cisangkuy No.2, Bandung, Indonesia

*Correspondence: Prodia Clinical Laboratory, Jl. Cisangkuy No.2, Bandung, Indonesia

e-mail: anna.meiliana@prodia.co.id
\end{abstract}

\section{Abstract}

$\mathrm{B}$ ACKGROUND: Mitochondrial function and behavior are central to the physiology of humans and, consequently, "mitochondrial dysfunction" has been implicated in a wide range of diseases.

\section{CONTENT: Mitochondrial ROS might attack various} mitochondrial constituents, causing mitochondrial DNA mutations and oxidative damage to respiratory enzymes. A defect in mitochondrial respiratory enzymes would increase mitochondrial production of ROS, causing further mitochondrial damage and dysfunction. Mitochondrial dysfunction is associated with diseases, such as neurodegenerative disorders, cardiomyopathies, metabolic syndrome, obesity, and cancer. Pathways that improve mitochondrial function, attenuate mitochondrial oxidative stress, and regulate mitochondrial biogenesis have recently emerged as potential therapeutic targets.

SUMMARY: Mitochondria perform diverse yet interconnected functions, produce ATP and many biosynthetic intermediates while also contribute to cellular stress responses such as autophagy and apoptosis. Mitochondria form a dynamic, interconnected network that is intimately integrated with other cellular compartments. It is therefore not surprising that mitochondrial dysfunction has emerged as a key factor in a myriad of diseases, including neurodegenerative, cancer, and metabolic disorders. Interventions that modulate processes involved in regulation of mitochondrial turnover, with calorie

\section{Abstrak}

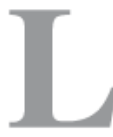

ATAR BELAKANG: Fungsi dan perilaku mitokondria memegang peran kunci pada fisiologi manusia, dan "disfungsi mitokondria" mempunyai dampak pada terjadinya berbagai macam penyakit metabolik.

ISI: Dampak Reactive Oxygen Species (ROS) mitokondria terhadap berbagai konstituennya, menyebabkan mutasi pada DNA mitokondria dan dapat merusak enzimenzim respiratori. Kerusakan pada enzim respiratori akan meningkatkan produksi ROS pada mitokondria, yang selanjutnya memperparah kerusakan dan disfungsi mitokondria. Disfungsi mitokondria terkait dengan berbagai macam penyakit seperti gangguan neurodegeneratif, kardiomiopati, sindrom metabolik, obesitas, dan kanker. Target terapi pada dewasa ini diarahkan kepada cara untuk memperbaiki fungsi mitokondria, meredam stres oksidatif pada mitokondria, dan mengendalikan biogenesis mitokondria.

RINGKASAN: Mitokondria berperan pada produksi ATP, zat perantara biosintesis, dan pada respon stres selular seperti autofagi dan apoptosis. Mitokondria membentuk suatu jaringan kompartemen selular yang dinamis, saling terhubung, dan terintegrasi sehingga tidak mengejutkan jika disfungsi mitokondria merupakan faktor kunci pada sejumlah besar penyakit, termasuk penyakit neurodegeneratif, kanker, dan gangguan metabolik. Intervensi yang bertujuan untuk memodulasi biogenesis 
restriction and induction of mitochondrial biogenesis, are of particular interest.

KEYWORDS: Mitochondrial Biogenesis, Mitochondrial Dysfunction, Reactive Oxygen Species (ROS), Metabolic Diseases

Indones Biomed J 2012; 4 (3): 119-128 dan proses metabolisme mitokondria, dengan cara restriksi kalori dan induksi biogenesis mitokondria menjadi hal yang sangat menjanjikan.

KEYWORDS: Biogenesis Mitokondria, Disfungsi Mitokondria, Reactive Oxygen Species (ROS), Penyakit Metabolik

Indones Biomed J 2012; 4 (3): 119-128

\section{Introduction}

Mitochondria play important roles in a myriad of cellular processes including ATP production via oxidative phosphorylation (OXPHOS), biosynthetic pathways, cellular redox homeostasis, ion homeostasis, oxygen sensing, signaling, and regulation of programmed cell death. Mitochondrial dysfunction is central in the theories of aging because age-related changes of mitochondria are likely to impair a host of cellular physiological functions in parallel and contribute to the development of all common age-related diseases (1).

The central roles of mitochondria in metabolism position them as key factors in global energy modulation. An increased need for ATP is met by increasing mitochondrial mass and inducing OXPHOS. For example, an increase of mitochondrial mass and activity is observed after endurance exercise (2). The regulation of mitochondrial biogenesis is tightly coordinated with pathways that induce vascularization, enhance oxygen delivery to tissues, and enable oxygen supply to facilitate efficient mitochondrial oxidization of glucose and fat (3).

Mitochondrial metabolism is both the basis and target of nutrient signals that ultimately orchestrate an integrated physiological response. The molecular components that sense energy status include transcription factors, hormones, cofactors, nuclear receptors, and kinases, which detect specific signals of mitochondrial activity, such as the NAD ${ }^{+} \mathrm{NADH}$ ratio, the AMP:ATP ratio, or acetyl-CoA levels (4).

Nutrient responses are likely to be highly tissue specific. In the liver, low blood lipid concentrations induce the nuclear PPAR-alpha receptor, which ultimately induces ketogenesis. In adipose tissue, mitochondriaderived starvation responses trigger lipolysis to provide peripheral tissues with fuels $(5,6)$. In the hypothalamus, AMPK affects neuronal plasticity and transmitter receptor activity to promote food intake and provide neuronal protection in response to hunger $(7,8)$. During a high nutritional load, multiple cell types exhibit high levels of ATP and NADH and the metabolic balance tips toward lipid and glycogen storage and mitochondrial biogenesis is downregulated, increasing glycolytic ATP synthesis (4).

How does the interrelationship between nutrient sensing and mitochondrial function contribute to disease? Not surprisingly, alterations in mitochondrial mass and activity are contributory factors in obesity and metabolic syndrome.

\section{Mitochondrial Biology and Function}

Mitochondria are ubiquitous membrane-bound organelles that are a defining feature of the eukaryotic cell. The organelle is comprised of a soluble matrix surrounded by a double membrane, an ion impermeable inner membrane, and a permeable outer membrane. Early biochemists recognized the importance of mitochondria as the sites of aerobic oxidation of metabolic fuels. It is now well established that they contribute to many important functions including pyruvate and fatty acid oxidation, nitrogen metabolism, and heme biosynthesis among others (9).

We now understand oxidative phosphorylation as a process catalyzed by constitutive proteins of the inner mitochondrial membrane that encompasses electron transfer between the complexes of the respiratory chain, vectorial $\mathrm{H}^{+}$release into the intermembrane space, and $\mathrm{H}^{+}$reentry to the matrix through F0 with ATP synthesis by the F1-ATP synthase. In addition, mitochondria are 
recognized to contribute to intracellular signaling and regulation with a central role in keeping homeostatic cell ionic composition (10).

The mitochondrial respiratory chain consists of a series of electron carriers that function as redox pairs and that are mainly prosthetic groups of integral proteins. There are four electron transfer or respiratory complexes (complexes I-IV), each capable of catalyzing electron transfer in a partial reaction of the respiratory chain (11).

Mitochondrial ATP production (oxidative phosphorylation) is driven by the transfer of electrons from NADH and FADH2 to $\mathrm{O}_{2}$ through Complexes I-IV of electron transport chain. The released energy allows components of Complexes I, III and IV to pump protons $\left(\mathrm{H}^{+}\right)$across the inner mitochondrial membrane. This creates an electrochemical $\mathrm{H}^{+}$gradient (called proton motive force, $\Delta \mu \mathrm{H}^{+}$) that provides energy for ATP synthesis. The movement of protons back across the inner mitochondrial membrane driven by the proton motive force is coupled with the synthesis of ATP by the mitochondrial ATP synthase. The whole process is called the oxidative phosphorylation. Any proton re-entry bypassing ATP synthase leads to uncoupling of oxidative phosphorylation. A well-known example of such an uncoupling of respiration from ATP synthesis is represented by uncoupling proteins (UCPs) (12).

Mitochondria are a principal source of cellular reactive oxygen species (ROS). Whereas mitochondrial ROS production has commonly been thought as solely the result of inefficiencies in the electron transport chain. Mitochondrial production of ROS is also a tightly controlled process and plays a role in the maintenance of cellular oxidative homeostasis and propagation of cellular signaling pathways. Production of ROS at the mitochondria thus integrates cellular energy state, metabolite concentration, and other upstream signaling events and has important implications in cellular stress signaling, maintenance of stem cell populations, cellular survival, and oncogenic transformation (13).

ROS are produced by mitochondria during oxidative metabolism through the one-electron reduction of molecular oxygen $\left(\mathrm{O}_{2}\right)$, forming superoxide anion $\left(\mathrm{O}_{2} \bullet-\right)$. Superoxide is the proximal ROS produced by mitochondria and is converted to hydrogen peroxide $\left(\mathrm{H}_{2} \mathrm{O}_{2}\right)$ through the action of superoxide dismutases (SODs) both within the mitochondria and in the cytosol. Complexes I, II, and III of the electron transport chain contain sites wherein electrons can prematurely reduce oxygen, resulting in the formation of superoxide $(14,15)$. Although complexes I and II produce ROS only into the matrix, complex III can produce ROS on both sides of the mitochondrial inner membrane $(14,16)$. This is of interest in the field of signaling, because ROS produced into the intermembrane space theoretically have an easier route to the cytosol to act as signaling molecules than do ROS produced into the matrix (17).

ROS production by mitochondria can lead to oxidative damage to mitochondrial proteins, membranes and DNA, impairing the ability of mitochondria to synthesize ATP and to carry out their wide range of metabolic

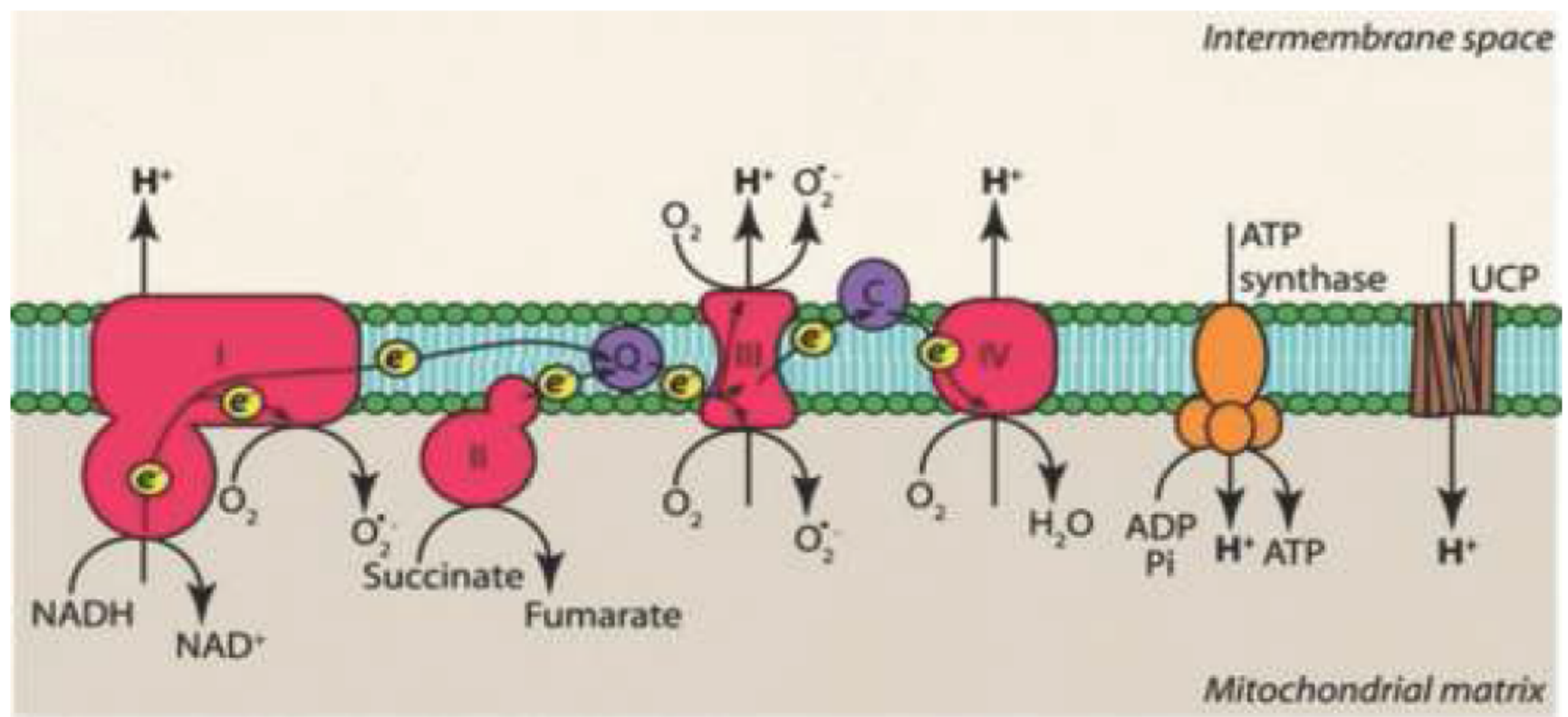

Figure 1. Mitochondrial ATP production (Adapted with permission from Trifunovic A et al. Blackwell Publishing Ltd 2008). 


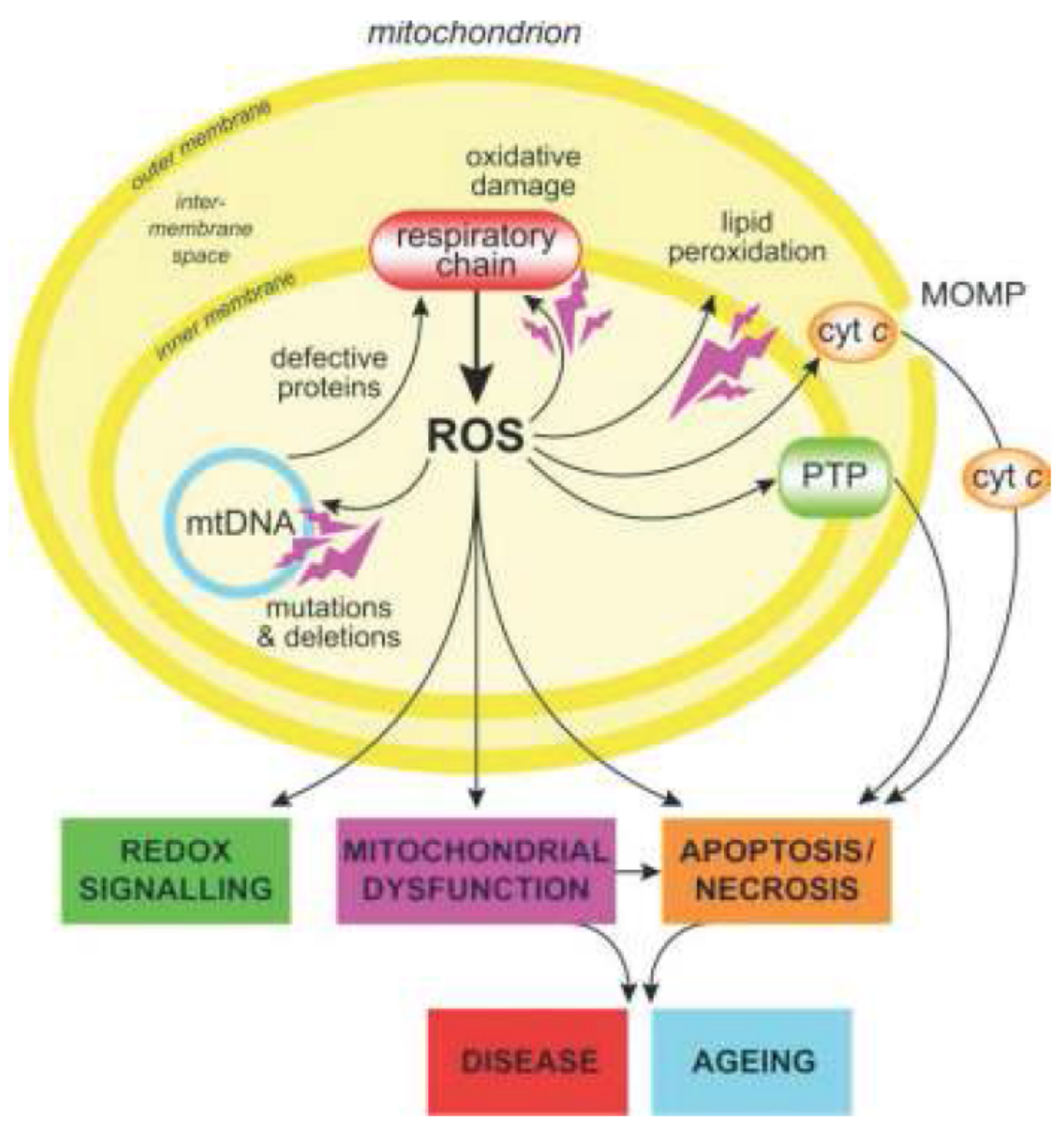

Figure 2. Overview of mitochondrial ROS production (Adapted with permission from Murphy MP, Creative Commons Attribution Non - commercial Licence, 2008).

functions, including the tricarboxylic acid cycle, fatty acid oxidation, urea cycle, amino acid metabolism, hem synthesis and $\mathrm{FeS}$ centre assembly that are central to the normal operation of most cells. Mitochondrial oxidative damage can also increase the tendency of mitochondria to release intermembrane space proteins such as cytochrome c (cyt c) to the cytosol by mitochondrial outer membrane permeabilization (MOMP) and thereby activate the cell's apoptotic machinery. In addition, mitochondrial ROS production leads to induction of the mitochondrial permeability transition pore (PTP), which renders the inner membrane permeable to small molecules in situations such as ischemia/reperfusion injury. Consequently, it is unsurprising that mitochondrial oxidative damage contributes to a wide range of pathologies. In addition, mitochondrial ROS may act as a modulatable redox signal, reversibly affecting the activity of a range of functions in the mitochondria, cytosol and nucleus (15).

It is now clear that mammalian life span is negatively related to the mitochondrial production of oxidizing free radicals, and that dysfunctional mitochondria determine mitochondrial and cellular turnover. Mitochondrial impairment and cellular dysfunction upon aging determine tissue physiological function.

Mitochondrial biogenesis seems to be regulated by the signaling given by $\mathrm{NO}$ and $\mathrm{H}_{2} \mathrm{O}_{2}$ diffusion from mitochondria to the cytosol. The altered signaling by mitochondrial $\mathrm{NO}$ and $\mathrm{H}_{2} \mathrm{O}_{2}$ appears to be a likely explanation for the decreased mitochondrial biogenesis in aging, a process that definitively contributes to cellular energy deficits, apoptosis, and tissue physiological failure in aging (11). 


\section{Mitochondrial Proteins}

The mitochondrion is endowed with all the elements necessary for protein synthesis: it harbors its own genomein the guise of a circular $\sim 16.5-\mathrm{kb}$ chromosomeand transcription and translation apparatus. However, mitochondrial DNA (mtDNA) has just 37 genes, which encode 22 mitochondrial tRNAs, 2 mitochondrial rRNAs, and only 13 protein subunits belonging to respiratory complexes I, III, IV, and V1; all the subunits of complex II and the $>1000$ other proteins needed within the mitochondrion for its proper functioning are transcribed from nuclear genes, synthesized in the cytosol, and then transported into the organelle, where many are further posttranslationally processed before being located into position (18).

Most mitochondrial proteins are synthesized on cytosolic ribosomes and must be imported across one or both mitochondrial membranes. There is an amazingly versatile set of machineries and mechanisms, and at least four different pathways, for the importing and sorting of mitochondrial precursor proteins (19). Mitochondrial proteins function in energy metabolism, metabolism of amino acids, lipids, heme and iron, as transporters for metabolites, protein transport and folding, protein degradation, signaling processes, membrane remodeling, fusion and fission, and also involved in programmed cell death (19).

The three-carbon molecule pyruvate is a metabolic intermediate and a central hub for cellular energy metabolism. It lies at the junction of aerobic and anaerobic metabolism and is the precursor for biosynthetic pathways including glucose, lipid, and amino acid synthesis. Given the ubiquitous role of pyruvate in cellular bioenergetics, its subcellular localization plays a critical role in its fate (20). The final product of pyruvate metabolism is fundamentally altered once it enters the mitochondrion. As such, the identity of the protein that transports pyruvate from the cytoplasm into mitochondria has been eagerly anticipated, and the wait has been nearly 40 years. Bricker et al. (21) and Herzig et al. (22), report the identification of a mitochondrial pyruvate carrier (MPC) responsible for this function-a momentous development in the field of bioenergetics with profound implications for treating metabolic diseases.

Given that the mitochondrial pyruvate transporter regulates a crucial branch point in cellular metabolism, its identification has enormous potential to treat human disease. Identification of the MPC also has implications for treating other pathologies, including heart failure, ischemia/reperfusion injury, and type 2 diabetes. Modulation of pyruvate transport could potentiate metabolic flexibility and respiratory capacity that might be beneficial to treating these diseases (20).

The mitochondrial inner membrane consists of two domains, inner boundary membrane and cristae membrane that are connected by crista junctions. Mitofilin/Fcj1 was reported to be involved in formation of crista junctions, however, different views exist on its function and possible partner proteins (23).

Mitofilin is part of a large multi-subunit protein complex in the inner membrane, termed mitochondrial inner membrane organizing system (MINOS) for its role in controlling cristae morphology. Additionally, mitofilin interacts with the outer membrane (TOM) Momplex and promotes protein import into the intermembrane space via the mitochondrial intermembrane (MIA) pathway (23). $\mathrm{VCP} / \mathrm{Cdc} 48$-associated mitochondrial stress responsive (Vms1) is a required component of an evolutionarily conserved system for mitochondrial protein degradation, which is necessary to maintain mitochondrial, cellular, and organismal viability (24).

Mitochondria are a complex organelle whose dysfunction underlies a broad spectrum of human diseases. Identifying all of the proteins residing in this organelle and understanding how they integrate into the pathways represent major challenges in cell biology (25).

\section{Mitochondrial Biogenesis,} Mitophagy and Apoptosis

Adipose tissue serves as source of adipokines and cMitochondria do not exist as discrete static entities; rather, mitochondria form a network that continuously moves, divides, and fuses. The structure of this dynamic network is in part maintained by a balance of division and fusion events (26). The ratio of division to fusion events that defines a proper balance is not universal but varies with developmental stage, cell type, and biological circumstances (27).

Mitochondria are essential organelles because they supply the cell with metabolic energy in the form of ATP generated by oxidative phosphorylation. In addition, they perform a number of other key metabolic reactions. Their shape, from spherical to elongated, is continually remodeled by fusion and fission that link all the organelles within a cell into a continuum over time. A 
host of pathways and enzymatic functions residing within mitochondria can modify and influence OXPHOS, and OXPHOS abnormalities can in turn generate signals that trigger either homeostatic pathways, e.g., mitochondrial biogenesis or execution programs, e.g., mitophagy, which eliminates single dysfunctional organelles, or apoptosis, which eliminates the whole dysfunctional cell (28).

Mitochondrial biogenesis can be defined as the growth and division of pre-existing mitochondria. According to the well-accepted endosymbiotic theory, mitochondria are the direct descendants of an aproteobacteria endosymbiont that became established in a host cell. Due to their ancient bacterial origin, mitochondria have their own genome and a capacity for autoreplication. Mitochondrial proteins are encoded by the nuclear and the mitochondrial genomes (29). Correct mitochondrial biogenesis relies on the spatiotemporally coordinated synthesis and import of $\sim 1000$ proteins encoded by the nuclear genome, of which some are assembled with proteins encoded by mitochondrial DNA within newly synthesized phospholipid membranes of the inner and outer mitochondrial membranes. In addition, mechanisms of mitochondrial DNA replication and mitochondrial fusion and fission must also be coordinated (29). Mitochondrial biogenesis is triggered by environmental stresses such as exercise, cold exposure, caloric restriction and oxidative stress, cell division and renewal, and differentiation. The biogenesis of mitochondria is accompanied by variations in mitochondrial size, number, and mass.

Mitochondria in cells of most tissues are tubular, and dynamic changes in morphology are driven by fission, fusion, and translocation (30). The ability to undergo fission/ fusion enables mitochondria to divide and helps ensure proper organization of the mitochondrial network during biogenesis. The processes of fission/fusion are controlled by GTPases, most of which have been identified in genetic screens in yeast $(26,31)$. Mitochondrial fission is driven by dynamin-related proteins (DRP1 and OPA1), while mitochondrial fusion is controlled by mitofusins (Mfn1 and 2). Mitofusins are highly expressed in heart and skeletal muscles, and their expression is induced during myogenesis and physical exercise $(32,33)$. In addition to the control of the mitochondrial network, Mfn2 also stimulates the mitochondrial oxidation of substrates, cell respiration, and mitochondrial membrane potential, suggesting that this protein may play an important role in mitochondrial metabolism, and as a consequence, in energy balance (32). OPA1, by contrast, is involved in the remodeling of cristae. Mfn and DRP1 expression increases in parallel with mitochondrial content and exercise capacity in human skeletal muscle (34), suggesting that fusion/fission processes are an integral part of mitochondrial biogenesis. Cardiolipin plays a key role in the activity of several inner membrane proteins and in the binding of mitochondrial creatine kinase in the vicinity of translocase (35).

Mitochondrial biogenesis and respiration are stimulated by PGC- $1 \alpha$ through powerful induction of NRF1 and NRF2 gene expression. PGC-1 $\alpha$ is enriched in tissue with high oxidative activity-like heart and brown adipose tissue and, to a lesser extent, skeletal muscle and kidney, and it is rapidly induced under conditions of increased energy demand such as cold, exercise, and fasting. Data are accumulating which show PGC- $1 \alpha$ to be a master regulator of mitochondrial biogenesis in mammals (29).

In cells, organelles called lysosomes are responsible for breaking down a wide range of cellular material such as proteins and other organelles, through a process known as autophagy (36). When nutrients are scarce, autophagy allows a cell to break down its own components and recycle important molecules (37). Degradation inside autophagosomes occurs when lysosomes fuse with the autophagosome and infuse it with enzymes that break down the cargo (38). The ultimate purpose of autophagy is to break down the cargo and recycle essential macromolecules, and this only occurs once the lysosomal hydrolases reach the autophagosome through fusion (38). Defective autophagy has been linked to common human diseases such as neurodegenerative conditions (e.g., Alzheimer's disease, Parkinson's disease), metabolic disorders (diabetes, obesity), and aging. The formation of autophagosomes is intact or even enhanced in many of these pathologies; it is the failure to degrade these structures that compromises cellular viability (39). Autophagy, a tightly regulated process by which cells consume unwanted cytoplasmic macromolecular constituents and recycle nutrients for cellular remodeling, is mediated by the coordinated activity of autophagy-specific (ATG) genes (40).

Recently, mitochondrial fission has been linked to the cellular death program of apoptosis. Mitochondria are involved in the so-called intrinsic pathway of apoptosis where they release soluble proteins, including cytochrome $\mathrm{C}$, from the intermembrane space to initiate caspase activation in the cytosol $(41,42)$. The release of these proteins is a consequence of the integrity of the mitochondrial outer membrane (OMM) being compromised, a process called mitochondrial outer membrane permeabilization (MOMP).

Many signaling pathways have been shown to be involved in mitochondrial biogenesis. Whether they directly control PGC- $1 \alpha$ expression or whether they 
impaired energy metabolism, still need more work in this growing area. The PGC-1a axis however could be envisioned as a new, exciting therapeutic target in metabolic disorders and heart failure.

\section{Mitochondrial Dysfunction and Metabolic Disease}

In the last 20 years mitochondrial dysfunction has been recognized as an important contributor to an array of human pathologies. Mitochondrial defects play a direct role in certain well-defined neuromuscular diseases and are also thought to contribute indirectly in many degenerative diseases.

Mitochondria are highly dynamic organelles, and their biogenesis is likely to be involved in the regulation of endothelial cell metabolism, redox regulation, and signal transduction. Impairment of mitochondrial biogenesis is frequently observed in diabetes and the metabolic syndrome (43) and is thus likely to contribute to cellular energetic imbalance, oxidative stress, and endothelial dysfunction in these pathological conditions (44). It has become increasingly evident that mitochondrial dysfunction can result from more causes than previously thought (inherited OXPHOS diseases) and that the onset and progression of several diseases often depends on the severity of the mitochondrial dysfunction (45).

Dysfunctional mitochondria are characterized by decreased state 3 respiration, respiratory controls, and membrane potential, and increased rates of state 4 respiration and mitochondrial size and fragility associated to an increased content of oxidation products (46-49). In humans, insulin resistance in the skeletal muscle has been associated with a lower ratio of oxidative type 1 to type 2 glycolytic type muscle fibers, decreased mitochondrial oxidative capacity and ATP synthesis, and, lastly, decreased expression of genes that control mitochondrial activity (50-52). One gene whose decreased expression is consistently implicated in the human or animal diabetic muscle is the PGC- $1 \alpha(50,53,54)$. PGC- $1 \alpha$ is a coactivator with pleiotropic functions $(55,56)$. Most importantly, PGC- $1 \alpha$ controls mitochondrial biogenesis and function, which in the muscle can contribute to fibertype switching (57) and, in the brown adipose tissue (BAT), to adaptive thermogenesis (58). Transcriptional activators and coactivators that regulate mitochondrial biogenesis have been suggested as potential contributors to this phenomenon (9).

\section{Therapeutic Strategies to Improve Mitochondrial Function}

Mitochondria are highly dynamic organelles, and dysregulation of mitochondrial turnover is likely to be one of the intrinsic causes of mitochondrial dysfunction, which contributes to dysregulation of cell metabolism, oxidative stress, and altered signal transduction. Pathways that improve mitochondrial function, attenuate mitochondrial oxidative stress, and regulate mitochondrial biogenesis have recently emerged as potential therapeutic targets.

AMPK is a crucial cellular energy sensor. Once activated by falling energy status, it promotes ATP production by increasing the activity or expression of proteins involved in catabolism while conserving ATP by switching off biosynthetic pathways. AMPK also regulates metabolic energy balance at the whole-body level (58). AMPK is also switched on by numerous drugs and xenobiotics, including antidiabetic drugs (such as metformin, phenformin, and thiazolidinediones $(59,60))$, plant products reputed to have health-promoting properties (resveratrol from grapes and red wine (61), epigalocatechin gallate from green tea, capsaicin from peppers (62), curcumin from turmeric (63) and even garlic (64) and plant products used in Chinese medicine (berberine (65) and hispidulin (66)). Another crucial process activated by AMPK is mitochondrial biogenesis which in the longer term generates increased capacity for the oxidative catabolism of both glucose and fatty acids (58).

The "master regulator" of mitochondrial biogenesis is PGC1 $\alpha$, a co-activator enhances the activity of several transcription factors acting on nuclear-encoded mitochondrial genes (67). AMPK directly phosphorylates PGC1 $\alpha$, which has been proposed to cause activation of its own transcription via a positive feedback loop (68). AMPK acts as the prime initial sensor that translates this information into SIRT1-dependent deacetylation of the transcriptional regulators PGC- $1 \alpha$ and FOXO1, culminating in the transcriptional modulation of mitochondrial and lipid utilization genes (69).

As well as increasing mitochondrial biogenesis, AMPK is involved in the turnover of mitochondria via the special form of autophagy termed mitophagy. UNC51 like kinase (ULK-1) and ULK-2, the mammalian ortholouges of the yeast Atg1 kinase that initiates the autophagy cascade, form stable complexes with AMPK (70), and AMPK phosphorylates and activates ULK1, thus triggering autophagy $(71,72)$. This supports the idea that 
phosphorylation of ULK1 by AMPK is required for the clearance of dysfunctional mitochondria. Mitochondria are the main site of production of ROS in the cell and are particularly susceptible to oxidative damage. By recycling components of damaged mitochondria, mitophagy may be as important in maintaining a healthy cellular ATP-generating capacity as in the production of new mitochondria (58).

In mice, treatment with resveratrol (3,5,4'trihydroxystil-bene), a diet-derived polyphenol, improved mitochondrial function and biogenesis in the skeletal muscle (73) and the liver (61). Studies in diabetic mice demonstrated that resveratrol treatment improves endothelial function and attenuates vascular inflammation in diabetes mellitus (74-78) and extends longevity $(61,74)$. Similar protective effects of resveratrol treatment were observed in aged mice $(74,79)$. As noted above, both diabetes and aging are characterized by impaired mitochondrial biogenesis (80).

The mechanisms underlying the beneficial effects of calorie restriction are multifaceted, and include normalization of mitochondrial biogenesis $(81,82)$, attenuation of mitochondrial ROS production (83-85), and consequential inhibition of signaling pathways regulated by mitochondria-derived ROS (eg, NF- $\varkappa$ B) (86). The cellular pathways involved in mitochondrial protection induced by calorie restriction appear to depend on an increased expression/activity of the $\mathrm{NAD}^{+}$-dependent histone deacetylase SIRT1111 and activation of its downstream effectors, including PGC-1 $\alpha(82,83)$. These effects mediated by SIRT1 are likely potentiated by an increased bioavailability of nitric oxide and increased levels of adiponectin (87). Calorie restriction can also activate the transcription factor Nrf2, which controls the expression of numerous ROS detoxifying and antioxidant genes involved in regulation of mitochondrial redox homeostasis (88).

The potential mechanisms underlying the mitochondrial effects of exercise are likely multifaceted and may include an increased shear stress-induced NO production, altered metabolism, and neurohormonal effects (1). Because meta-analyses of clinical studies applying nontargeted antioxidants have shown disappointing results (89), several specific mitochondrial-targeted antioxidants have been developed. Triphenylphosphonium ion (TPP+) has been successfully used to deliver several lipophylic antioxidants to the mitochondrial matrix, including Mito-Q (coenzyme Q), mitovitamin E, and mitophenyltertbutyline as well as SkQ1 (plastoquinone). These mitochondrialtargeted drugs can achieve concentrations in the mitochondrial matrix 100 - to 1000 -fold higher than those in the cytosol because of their strong positive charge, as mitochondria have a highly negative membrane potential (approximately $\sim 150 \mathrm{mV}$ ) (1).

\section{Conclusions}

Mitochondrial function and behavior are central in the physiology of humans and, consequently, "mitochondrial dysfunction" has been implicated in a wide range of diseases. The complexity of mitochondrial functions and thus "mitochondrial dysfunction," however, are challenges to unravel, but these challenges must be met to determine whether mitochondrial manipulation can be harnessed therapeutically.

Recent technological developments will allow for systems based biochemical, metabolic and genomic approaches, which will provide invaluable insight into mitochondrial biology. These approaches will enable the construction of a complete mitochondrial network map that will be invaluable for understanding the role of "mitochondrial dysfunction" in human disease.

\section{References:}

1. Dai DF, Rabinovitch PS, Ungvari Z. Mitochondria and Cardiovascular Aging. Circ Res 2012; 110: 1109-24.

2. Hoppeler $\mathrm{H}$, Fluck M. Plasticity of skeletal muscle mitochondria: structure and function. Med. Sci. Sports Exerc. 2003; 35: 95-104.

3. Arany Z, Foo SY, Ma Y, Ruas JL, Bommi-Reddy A, Girnun G, et al. HIF-independent regulation of VEGF and angiogenesis by the transcriptional coactivator PGC-1alpha. Nature 2008; 451: 1008-12.

4. Nunnanri J, Suomalainen A. Mitochondria: in sickness and in health. Cell 2012; 148: 1145-59.

5. Kharitonenkov A, Shiyanova TL, Koester A, Ford AM, Micanovic $\mathrm{R}$, Galbreath EJ, et al. FGF-21 as a novel metabolic regulator. J. Clin. Invest. 2005; 115: 1627-35.

6. Nishimura T, Nakatake Y, Konishi M, Itoh N. Identification of a novel FGF, FGF-21, preferentially expressed in the liver. Biochim. Biophys. Acta 2000; 1492: 203-6.

7. Kuramoto N, Wilkins ME, Fairfax BP, Revilla-Sanchez R, Terunuma M, Tamaki K, et al. Phospho-dependent functional modulation of $\mathrm{GABA}(\mathrm{B})$ receptors by the metabolic sensor AMP-dependent protein kinase. Neuron 2007; 53: 233-47.

8. Yang Y, Atasoy D, Su HH, Sternson SM. Hunger states switch a flip-flop memory circuit via a synaptic AMPK-dependent positive feedback loop. Cell 2011; 146: 992-1003.

9. Scarpulla RC. Transcriptional paradigms in mammalian mitochondrial biogenesis and function. Physiol Rev 2008; 88: 611-38.

10. Darley-Usmar V. The powerhouse takes control of the cell; the role of mitochondria in signal transduction. Free Radic Biol Med 2004; 37: 753-4. 
11. Navarro A, Boveris A. The mitochondrial energy transduction system and the aging process. Am J Physiol Cell Physiol 2007; 292: C670-86.

12. Trifunovic A, Larsson NG. Mitochondrial dysfunction as a cause of ageing. J Intern Med 2008; 263: 167-78.

13. Hamanaka RB, Chandel NS. Mitochondrial reactive oxygen species regulate cellular signaling and dictate biological outcomes. Trends Biochem Sci 2010; 35: 505-13.

14. Turrens JF. Mitochondrial formation of reactive oxygen species. J Physiol 2003; 552: 335-44.

15. Murphy MP. How mitochondria produce reactive oxygen species. Biochem J 2009; 417: 1-13.

16. Muller FL, Liu Y, Van Remmen H. Complex III releases superoxide to both sides of the inner mitochondrial membrane. J Biol Chem 2004; 279: 49064-73.

17. Han D, Antunes F, Canali R, Rettori D, Cadenas E. Voltagedependent anion channels control the release of the superoxide anion from mitochondria to cytosol. J Biol Chem 2003; 278: 5557-63.

18. Latronico MVG, Condorelli G. The might of microRNA in mitochondria. Circ Res 2012; 110: 1540-2.

19. Chacinska A, Koehler CM, Milenkovic D, Lithgow T, Pfanner N. Importing mitochondrial proteins: machineries and mechanisms. Cell 2009; 138: 628-44.

20. Divakaruni AS, Murphy AN. A mitochondrial mystery, solved. Science 2012; 337: 41-3.

21. Bricker DK, Taylor EB, Schell JC, Orsak T, Boutron A, Chen YC, et al. A mitochondrial pyruvate carrier required for pyruvate uptake in yeast, Drosophila, and humans. Science 2012; 337: 96-100.

22. Herzig S, Raemy E, Montessuit S, Veuthey JL, Zambon $\mathrm{N}$, Westermann B, et al. Identification and functional expression of the mitochondrial pyruvate carrier. Science 2012; 337: 93-6.

23. Von der Malsburg K, Muller JM, Bohnert M, Oeljeklaus S, Kwiatkowska $\mathrm{P}$, Becker $\mathrm{T}$, et al. Dual role of mitofilin in mitochondrial membrane organization and protein biogenesis. Dev Cell 2011; 21: 694-707.

24. Heo JM, Livnat - Levanon N, Taylor EB, Jones KT, Dephoure N, Ring J, et al. A stress-responsive system for mitochondrial protein degradation. Mol Cell 2010; 40: 465-80.

25. Pagliarini DJ, Calvo SE, Chang B, Sheth BC, Vafai SB, Ong $\mathrm{SE}$, et al. A mitochondrial protein compendium elucidates complex I disease biology. Cell 2008; 134: 112-23.

26. Hoppins S, Lackner L, Nunnari J. The machines that divide and fuse mitochondria. Annu. Rev. Biochem. 2007; 76: 751-80.

27. Lackner LL, Nunnari J. Small molecule inhibitors of mitochondrial division: tools that translate basic biological research into medicine. Chem Biol 2010; 17: 578-83.

28. Goldman SJ, Taylor R, Zhang Y, Jin S. Autophagy and the degradation of mitochondria. Mitochondrion 2010; 10: 30915.

29. Ventura - Clapier R, Garnier A, Veksler V. Transcriptional control of mitochondrial biogenesis: the central role fo PGC-1 Cardiovasc Res 2008; 79: 208-17.

30. Bereiter-Hahn J. Behavior of mitochondria in the living cell. Int Rev Cytol 1990; 122: 1-63.

31. Chan DC. Mitochondria: dynamic organelles in disease, aging and devel- opment. Cell 2006; 125: 1241-52.

32. Bach D, Pich S, Soriano FX, Vega N, Baumgartner B, Oriola $\mathrm{J}$ et al. Mitofusin-2 determines mitochondrial network architecture and mitochondrial metabolism. A novel regulatory mechanism altered in obesity. J Biol Chem 2003; 278: 17190-7.

33. Soriano FX, Liesa M, Bach D, Chan DC, Palacin M, Zorzano A. Evidence for a mitochondrial regulatory pathway defined by peroxisome proliferator-activated receptor-gamma coactivator-1 alpha, estrogen-related receptor-alpha, and mitofusin-2. Diabetes 2006; 55: 1783-91.

34. Garnier A, Fortin D, Zoll J, N'Guessan B, Mettauer B, Lampert $\mathrm{E}$ et al. Coordinated changes in mitochondrial function and biogenesis in healthy and diseased human skeletal muscle. FASEB J 2005; 19: 43-52.

35. Hatch GM. Cell biology of cardiac mitochondrial phospholipids. Biochem Cell Biol 2004; 82: 99-112.

36. Yang Z, Klionsky DJ. Eaten alive: a history of macroautophagy. Nat Cell Biol 2010; 12: 814 .

37. Mizushima N, Yamamoto A, Matsui M, Yoshimori T, Ohsumi Y. In vivo analysis of autophagy in response to nutrient starvation using transgenic mice expressing a fluorescent autophagosome marker. Mol Biol Cell 2004; 15: 1101-11.

38. Cuervo AM. Autophagy's top chef. Science 2011; 332: 1392-3.

39. Wong E, Cuervo AM. Autophagy gone awry in neurodegenerative diseases. Nat. Neurosci. 2010; 13: 805-11.

40. Till A, Subramani S. A balancing act for autophagin. J Clin Invest 2010; 120: 2273-6.

41. Kroemer G, Galluzzi L, Brenner C. Mitochondrial membrane permeabilization in cell death. Physiol. Rev. 2007; 87: 99163.

42. Vaux DL. Apoptogenic factors released from mitochondria. Biochem Biophys Acta 2011; 1813: 546-50.

43. Nisoli E, Clementi E, Carruba MO, Moncada S. Defective mitochondrial biogenesis: a hallmark of the high cardiovascular risk in the metabolic syndrome? Circ Res 2007; 100: 795-806.

44. Gutierrez J, Ballinger SW, Darley-Usmar VM, Landar A. Free radicals, mitochondria, and oxidized lipids: the emerging role in signal transduction in vascular cells. Circ Res 2006; 99: 924-32.

45. Benit $P$, Rustin $P$. Changing the diet to make more mitochondria and protect the heart. Circ Res 2012; 110: 1047-8.

46. Beckman KB, Ames BN. The free radical theory of aging matures. Physiol Rev 1998; 78: 547-81.

47. Gonzalez-Flecha B, Cutrin JC, Boveris A. Time course and mechanism of oxidative stress and tissue damage in rat liver subjected to in vivo ischemia-reperfusion. J Clin Invest 1993; 91: 456-64

48. Navarro A, Boveris A. Rat brain and liver mitochondria develop oxidative stress and lose enzymatic activities on aging. Am J Physiol Regul Integr Comp Physiol 2004; 287: R1244-9.

49. Navarro A, Gomez C, Sanchez-Pino MJ, Gonzalez H, Bandez $\mathrm{MJ}$, Boveris $A D$, et al. Vitamin $E$ at high doses improves survival, neurological performance, and brain mitochondrial function in aging male mice. Am J Physiol Regul Integr Comp Physiol 2005; 289: R1392-9.

50. Mootha VK, Handschin C, Arlow D, Xie X, St Pierre J, Sihag S, et al. Erralpha and Gabpa/b specify PGC-1alpha-dependent oxidative phosphorylation gene expression that is altered in diabetic muscle. Proc. Natl. Acad. Sci. USA 2004; 101: $6570-5$.

51. Patti ME, Butte AJ, Crunkhorn S, Cusi K, Berria R, Kashyap S, et al. Co-ordinated reduction of genes of oxidative metabolism in humans with insulin resistance and diabetes: Potential role of PGC1 and NRF1. Proc. Natl. Acad. Sci. USA 2003; 100: 8466-71.

52. Petersen KF, Befroy D, Dufour S, Dziura J, Ariyan C, Rothman DL Mitochondrial dysfunction in the elderly: possible role in insulin resistance. Science 2003; 300: 1140-2.

53. Sparks LM, Xie H, Koza RA, Mynatt R, Hulver MW, Bray GA, et al. A high-fat diet coordinately downregulates genes required for mitochondrial oxidative phosphorylation in skeletal muscle. Diabetes 2005; 54: 1926-33.

54. Knutti D, Kralli A. PGC-1, a versatile coactivator. Trends Endocrinol. Metab. 2001; 12: 360-5. 
55. Lin J, Wu H, Tarr PT, Zhang CY, Wu Z, Boss O, et al. Transcriptional co-activator PGC-1 alpha drives the formation of slowtwitch muscle fibres. Nature 2002; 418: 797-801.

56. Puigserver P, Wu Z, Park CW, Graves R, Wright M, Spiegelman BM. A cold-inducible coactivator of nuclear receptors linked to adaptive thermogenesis. Cell 1998; 92: 829-39.

57. Patti ME. Gene expression in humans with diabetes and prediabetes: what have we learned about diabetes pathophysiology? Curr Opin Clin Nutr Metab Care 2004; 7: 383-90.

58. Hardie DG, Ross FA, Hawley SA. AMPK: a nutrient and energy sensor that maintains energy hoemostasis. Nat Rev Mol Cell Biol 2012; 13: 251-62.

59. Zhou G, Myers R, Li Y, Chen Y, Shen X, Fenyk-Melody J, et al. Role of AMP-activated protein kinase in mechanism of metformin action. J Clin Invest. 2001; 108: 1167-74.

60. Fryer LG, Parbu-Patel A, Carling D. The Anti-diabetic drugs rosiglitazone and metformin stimulate AMP-activated protein kinase through distinct signaling pathways. J Biol Chem. 2002; 277: 25226-32.

61. Baur JA, Pearson KJ, Price NL, Jamieson HA, Lerin C, Kalra A, et al. Resveratrol improves health and survival of mice on a high-calorie diet. Nature. 2006; 444: 337-42.

62. Hwang JT, Park IJ, Shin JI, Lee YK, Lee SK, Baik HW, et al. Genistein, EGCG, and capsaicin inhibit adipocyte differentiation process via activating AMP-activated protein kinase. Biochem Biophys Res Commun. 2005; 338: 694-9.

63. Lim HW, Lim HY, Wong KP. Uncoupling of oxidative phosphorylation by curcumin: implication of its cellular mechanism of action. Biochem Biophys Res Commun. 2009; 389: 187-92.

64. Lee MS, Kim IH, Kim CT, Kim Y. Reduction of body weight by dietary garlic is associated with an increase in uncoupling protein mRNA expression and activation of AMP-activated protein kinase in diet-induced obese mice. J Nutr. 2011; 141: 1947-53.

65. Lee YS, Kim WS, Kim KH, Yoon MJ, Cho HJ, Shen Y, et al. Berberine, a natural plant product, activates AMP-activated protein kinase with beneficial metabolic effects in diabetic and insulin-resistant states. Diabetes. 2006; 55: 2256-64.

66. Lin YC, Hung CM, Tsai JC, Lee JC, Chen YL, Wei CW, et al. Hispidulin potently inhibits human glioblastoma multiforme cells through activation of AMP-activated protein kinase (AMPK). J Agric Food Chem. 2010; 58: 9511-7.

67. Lin J, Handschin C, Spiegelman BM. Metabolic control through the PGC-1 family of transcription coactivators. Cell Metab. 2005; 1: 361-70.

68. Jäger S, Handschin C, St-Pierre J, Spiegelman BM. AMPactivated protein kinase (AMPK) action in skeletal muscle via direct phosphorylation of PGC-1alpha. Proc Natl Acad Sci U S A. 2007; 104: 12017-22,

69. Canto C, Jiang LQ, Deshmukh AS, Mataki C, Coste A, Lagouge $\mathrm{M}$, et al. Interdependence of AMPK and SIRT1 for metabolic adaptation to fasting and exercise in skeletal muscle. Cell Metab 2010; 11: 213-9.

70. Behrends C, Sowa ME, Gygi SP, Harper JW. Network organization of the human autophagy system. Nature. 2010; 466: 68-76.

71. Egan DF, Shackelford DB, Mihaylova MM, Gelino S, Kohnz RA, Mair W, et al. Phosphorylation of ULK1 (hATG1) by AMP-activated protein kinase connects energy sensing to mitophagy. Science. 2011; 331: 456-61.

72. Kim J, Kundu M, Viollet B, Guan KL. AMPK and mTOR regulate autophagy through direct phosphorylation of Ulk1. Nat Cell Biol. 2011; 13: 132-41.

73. Lagouge M, Argmann C, Gerhart-Hines Z, Meziane H, Lerin C, Daussin F, et al. Resveratrol improves mitochondrial function and protects against metabolic disease by activating SIRT1 and PGC-1alpha. Cell 2006; 127: 110922.
74. Pearson KJ, Baur JA, Lewis KN, Peshkin L, Price NL, Labinskyy $\mathrm{N}$, et al. Resveratrol delays age-related deterioration and mimics transcriptional aspects of dietary restriction without extending life span. Cell Metab 2008; 8: 157-68.

75. Sharma S, Anjaneyulu M, Kulkarni SK, Chopra K. Resveratrol, a polyphenolic phytoalexin, attenuates diabetic nephropathy in rats. Pharmacology 2006; 76: 69-75.

76. Su HC, Hung LM, Chen JK. Resveratrol, a red wine antioxidant, possesses an insulin-like effect in streptozotocin-induced diabetic rats. Am J Physiol Endocrinol Metab 2006; 290 : E1339-46.

77. Thirunavukkarasu M, Penumathsa SV, Koneru S, Juhasz B, Zhan L, Otani H, Bagchi D, et al. Resveratrol alleviates cardiac dysfunction in streptozotocin-induced diabetes: role of nitric oxide, thioredoxin, and heme oxygenase. Free Radic Biol Med 2007; 43: 720-9.

78. Zang M, Xu S, Maitland-Toolan KA, Zuccollo A, Hou X, Jiang $\mathrm{B}$, et al. Polyphenols stimulate AMP-activated protein kinase, lower lipids, and inhibit accelerated atherosclerosis in diabetic LDL receptor-deficient mice. Diabetes 2006; 55: 2180-91.

79. Ungvari Zl, Orosz Z, Labinskyy N, Rivera A, Xiangmin Z, Smith $\mathrm{K}$, et al. Increased mitochondrial $\mathrm{H} 2 \mathrm{O} 2$ production promotes endothelial NF-KB activation in aged rat arteries. Am J Physiol Heart Circ Physiol 2007; 293: H37-47.

80. Csiszar A, Labinskyy N, Pinto JT, Ballabh P, Zhang H, Losonczy $\mathrm{G}$, et al. Resveratrol induces mitochondrial biogenesis in endothelial cells. Am J Physiol Heart Circ Physiol 2009; 297: H13-20.

81. Lopez-Lluch G, Hunt N, Jones B, Zhu M, Jamieson H, Hilmer S, et al. Calorie restriction induces mitochondrial biogenesis and bioenergetic efficiency. Proc Natl Acad Sci U S A. 2006; 103: 1768-73.

82. Lopez-Lluch G, Irusta PM, Navas P, de Cabo R. Mitochondrial biogenesis and healthy aging. Exp Gerontol. 2008; 43: 8139.

83. Nisoli E, Tonello C, Cardile A, Cozzi V, Bracale R, Tedesco L, et al. Calorie restriction promotes mitochondrial biogenesis by inducing the expression of enos. Science. 2005; 310: 3147.

84. Shinmura K, Tamaki K, Sano M, Nakashima-Kamimura N, Wolf $\mathrm{AM}$, Amo T, et al. Caloric restriction primes mitochondria for ischemic stress by deacetylating specific mitochondrial proteins of the electron transport chain. Circ Res. 2011; 109: 396-406.

85. Csiszar A, Labinskyy N, Jimenez R, Pinto JT, Ballabh P, Losonczy $\mathrm{G}$, et al. Anti-oxidative and antiinflammatory vasoprotective effects of caloric restriction in aging: role of circulating factors and sirt1. Mech Ageing Dev. 2009;130:518-27.

86. Cohen HY, Miller C, Bitterman KJ, Wall NR, Hekking B, Kessler $\mathrm{B}$, et al. Calorie restriction promotes mammalian cell survival by inducing the sirt1 deacetylase. Science. 2004; 305: 390-2.

87. Shinmura K, Tamaki K, Saito K, Nakano Y, Tobe T, Bolli R. Cardioprotective effects of short-term caloric restriction are mediated by adiponectin via activation of amp-activated protein kinase. Circulation. 2007;116:2809-17.

88. Pearson KJ, Lewis KN, Price NL, Chang JW, Perez E, Cascajo $\mathrm{MV}$, et al. Nrf2 mediates cancer protection but not prolongevity induced by caloric restriction. Proc Natl Acad Sci U S A. 2008; 105: 2325-30.

89. Bjelakovic G, Nikolova D, Gluud LL, Simonetti RG, Gluud C. Mortality in randomized trials of antioxidant supplements for primary and secondary prevention: systematic review and meta-analysis. JAMA. 2007; 297: 842-57. 